\title{
Recognition and enforcement of judgments in employment matters in European private international law
}

\author{
Uglješa Grušić*
}

\begin{abstract}
This article deals with the recognition and enforcement of judgments in employment matters in European private international law. After looking into the theoretical underpinnings of the protection of employees by rules of recognition and enforcement of foreign judgments, this article examines the recognition and enforcement of judgments concerning individual employment contracts under the Recast of the Brussels I Regulation, the European Enforcement Order Regulation and the European Order for Payment Procedure Regulation. It is shown that the lack of a jurisdictional defence for employment disputes in the latter two instruments has the potential to undermine, at the overlap of the fields of application of these instruments and the Brussels I Recast, the protection offered to employees by the Recast's jurisdictional defence.
\end{abstract}

Keywords: private international law; conflict of laws; European Union law; foreign judgments; recognition and enforcement; jurisdiction; employment contracts; protection of employees

\footnotetext{
*Assistant Professor, University of Nottingham; ugljesa.grusic@nottingham.ac.uk.
} 


\section{A. Introduction}

Research in law and economics shows that a successful economic union with free movement of goods, services, capital and persons cannot exist without free movement of judgments.

${ }^{1}$ This has long been recognised by the Member States of the European Union who are bound by the 2012 Recast of the Brussels I Regulation, which superseded the 2001 Brussels I Regulation, which, in turn, replaced in virtually all cases the 1968 Brussels Convention. $^{2}$

The Brussels I Recast, which applies to legal proceedings instituted on or after 10 January 2015 and to judgments given in legal proceedings instituted from this date, ${ }^{3}$ has introduced a number of changes in the law of adjudicatory jurisdiction and recognition and enforcement of judgments in civil and commercial matters. By far the most important change is the abolition of exequatur, i.e. the abolition of all intermediate procedures that the judgment creditor had to go through in order to obtain a declaration that the judgment given in one Member State is enforceable in the Member State addressed (or, in the UK, to register the judgment for enforcement) before proceeding to the execution of the judgment in the latter Member State. Enforcement of judgments is now automatic, in the sense that a judgment given in one Member State, accompanied by a certificate issued by the court of origin in a specified standard form and, in certain circumstances, by the translation or transliteration of these documents, is a sufficient basis for directly requesting enforcement measures in other Member States. It is left to those who want to oppose the recognition and

\footnotetext{
1 See R A Brand, "Recognition of Foreign Judgments as a Trade Law Issue: The Economics of Private International Law" in J S Bhandari and A O Sykes (eds), Economic Dimensions in International Law: Comparative and Empirical Perspectives (Cambridge University Press, 1997) 592.

2 Regulation (EU) No 1215/2012 of the European Parliament and of the Council of 12 December 2012 on jurisdiction and the recognition and enforcement of judgments in civil and commercial matters (Recast) [2012] OJ L351/1; Council Regulation (EC) No 44/2001 of 22 December 2000 on jurisdiction and the recognition and enforcement of judgments in civil and commercial matters 2001 OJ L12/1; 1968 Brussels Convention on jurisdiction and the enforcement of judgments in civil and commercial matters (consolidated version) [1998] OJ C27/1. The "Brussels regime" of jurisdiction and recognition and enforcement of judgments has been extended to three Member States of the European Free Trade Area, namely Iceland, Norway and Switzerland, by virtue of the 2007 Lugano Convention on jurisdiction and the recognition and enforcement of judgments in civil and commercial matters [2007] OJ L339/3, which superseded the 1988 Lugano Convention [1990] OJ C189/2.

${ }^{3}$ Art 66 of the Brussels I Recast; see also ibid, Art 81(2).
} 
enforcement of a judgment given by a Member State court to commence special proceedings for refusal of recognition and enforcement by invoking the grounds for refusal available under the Recast.

One of the other changes introduced by the Recast is the creation of an additional ground for refusal of recognition (and, therefore, enforcement) in Article 45(1)(e)(i): the recognition of a judgment shall be refused if the judgment conflicts with the rules of jurisdiction in employment matters that are set out in Section 5 of Chapter II of the Recast, but only where the employee was the defendant in the original proceedings. This ground for refusal of recognition complements the other three jurisdictional defences set out in Article 45(1)(e) for disputes concerning insurance and consumer matters and exclusive jurisdiction of Member State courts, which existed under the 2001 Brussels I Regulation and the 1968 Brussels Convention. ${ }^{4}$ Although the creation of the new jurisdictional defence for employment disputes is a welcome development, it is nevertheless surprising. The Heidelberg Report on the 2001 Brussels I Regulation ${ }^{5}$ concluded that the jurisdictional defences under this instrument were not only inconsistent, but also "not in line with the general principle of mutual trust" and that their "practical importance seems limited", and, therefore, recommended their complete removal. ${ }^{6}$ The Commission's proposal for a recast of the Brussels I Regulation ${ }^{7}$ followed the Heidelberg Report in this respect. This aspect of the Commission's proposal was not subject to criticism in the public debate that followed its publication, unlike many of its other provisions. But in the political process preceding the

\footnotetext{
${ }^{4}$ Art 35 of the 2001 Brussels I Regulation; Art 28 of the 1968 Brussels Convention.

${ }^{5}$ B Hess, T Pfeiffer and P Schlosser, Report on the Application of Regulation Brussels I in the Member States (September 2007) available at http://ec.europa.eu/civiljustice/news/docs/study application brussels 1 en.pdf, accessed 13 July 2016.

${ }^{6} \mathrm{Ibid}$, paras 564, 566, 632 and 901.

${ }^{7}$ European Commission, Proposal for a Regulation of the European Parliament and of the Council on jurisdiction and the recognition and enforcement of judgments in civil and commercial matters (recast) $\operatorname{COM}(2010) 748$ final.
} 
adoption of the Recast, ${ }^{8}$ the jurisdictional defences not only re-emerged, but were strengthened in number.

The adoption of the Recast represents the latest stage in a programme of measures for implementation of the principle of mutual recognition of decisions in civil and commercial matters adopted by the European Council on 30 November $2000 .{ }^{9}$ Among the other buildingblocks of this project are the European Enforcement Order Regulation, ${ }^{10}$ the European Order for Payment Procedure Regulation ${ }^{11}$ and the European Small Claims Procedure Regulation. ${ }^{12}$ These instruments had abolished the exequatur in their respective fields of application even before the adoption of the Brussels I Recast. A feature of these instruments is that they virtually bar judgment debtors from opposing the recognition and enforcement of judgments in the Member State addressed and greatly limit the possibilities of challenging the certification of judgments in the Member State of origin.

European private international law has become very complex because of the everincreasing number of European instruments that deal with cross-border civil and commercial matters and their overlapping and not always clear fields of application. It comes as no surprise that a lot of scholarly energy is being devoted to the exploration of the relationship between and among European private international law instruments. ${ }^{13}$ This article is connected to that debate through its examination of the relationship between and among the

\footnotetext{
${ }^{8}$ See J Fitchen in A Dickinson and E Lein (eds), The Brussels I Regulation Recast (Oxford University Press, 2015) para 13.371.

9 [2001] OJ C12/1. See also European Council, The Hague Programme: Strengthening Freedom, Security and Justice in the European Union [2005] OJ C53/1; European Council and European Commission, Action Plan Implementing the Hague Programme [2005] OJ C198/1; European Council, The Stockholm Programme - An Open and Secure Europe Serving and Protecting Citizens [2010] OJ C115/1.

${ }^{10}$ Regulation (EC) No 805/2004 of the European Parliament and of the Council of 21 April 2004 creating a European Enforcement Order for uncontested claims [2004] OJ L143/15.

${ }^{11}$ Regulation (EC) No 1896/2006 of the European Parliament and of the Council of 12 December 2006 creating a European order for payment procedure [2006] OJ L399/1.

${ }^{12}$ Regulation (EC) No 861/2007 of the European Parliament and of the Council of 11 July 2007 establishing a European Small Claims Procedure [2007] OJ L199/1.

${ }^{13}$ See E B Crawford and J M Carruthers, "Connection and Coherence Between and Among European Instruments in the Private International Law of Obligations' (2014) 63 International and Comparative Law Quarterly 1; E Lein, "The New Rome I / Rome II / Brussels I Synergy" (2008) 10 Yearbook of Private International Law 177.
} 
provisions on recognition and enforcement of judgments concerning individual employment contracts in European private international law. The focus of this article is the question whether, at the overlap of the fields of application of the Brussels I Recast and the other European instruments that deal with recognition and enforcement of judgments in civil and commercial matters, the goal of protection of employees, as enshrined in Article 45(1)(e)(i) of the Recast, is potentially undermined by the fact that the other European instruments lack a jurisdictional defence for employment disputes.

The discussion that follows is divided into three parts. The first part looks into the theoretical underpinnings of the protection of employees by rules of recognition and enforcement of foreign judgments. The second part examines the Recast's jurisdictional defence for employment disputes. The third part explores the potential application, and the consequences of the application, of the European Enforcement Order Regulation and the European Order for Payment Procedure Regulation to employment matters. The European Small Claims Procedure Regulation is not discussed because it expressly excludes employment matters from its scope. ${ }^{14}$ It is revealed that the jurisdictional defence for employment disputes performs a useful role under the Brussels I Recast and that the lack of an equivalent provision, which would ensure the correct application of the rules of jurisdiction in employment matters, in the European Enforcement Order Regulation and the European Order for Payment Procedure Regulation justifies a legislative intervention in any future process of review or recast of the latter two instruments. ${ }^{15}$

\section{B. Protection of employees by rules of recognition and enforcement of foreign}

\section{judgments}

\footnotetext{
${ }^{14}$ Art 2(2)(f) of the Small Claims Procedure Regulation.

${ }^{15}$ See in this respect European Parliament resolution of 8 October 2013 on improving private international law: jurisdiction rules applicable to employment (2013/2023(INI)) [2016] OJ C181/19.
} 
Employees are one of the categories of typically weaker parties that enjoy protection in many systems of private international law. Other categories include, for example, consumers and insured persons. The protection of such typically weaker parties at the stage of recognition and enforcement of foreign judgments is closely connected with their protection by rules of jurisdiction. Although this article focuses on protection offered to employees by rules of recognition and enforcement of foreign judgments, it is necessary to examine the rationale for the jurisdictional protection of employees. ${ }^{16}$ The following discussion is also relevant for the more general question of protection of all typically weaker parties.

The jurisdictional position of a party to a transnational employment dispute depends on whether that party acts as a claimant or as a defendant. Parties normally seek to bring their claims or to defend their cases in the forums that are most advantageous to them. The (dis)advantageous nature of a forum depends on many factors which include geographical proximity, neutrality (or even bias, actual or perceived, to a party), cultural and legal tradition, the existence of specialised labour courts or tribunals and special procedures for employment disputes, system of legal fees, availability of legal aid, operation of choice-oflaw rules etc. Since it is claimants who ordinarily select the forum when commencing proceedings, the parties' jurisdictional positions ultimately depend on the number and diversity of jurisdictional bases that are available to claimants. The more available and diverse the bases, the greater the chance that the claimant will bring his or her claim in an advantageous forum, but also that the defendant will have to defend his or her case in a disadvantageous forum.

\footnotetext{
${ }^{16}$ See U Grušić, The European Private International Law of Employment (Cambridge University Press, 2015) 49-54 and in general Ch 2.
} 
It is generally recognised that employees are typically weaker parties vis-à-vis their employers. It is because of the typical inequality in litigational capacity and bargaining power between employees and employers that the former enjoy a degree of jurisdictional protection in many systems of private international law. This idea is expressed in Recital 18 of the Brussels I Recast: "In relation to ... employment contracts, the weaker party should be protected by rules of jurisdiction more favourable to his interests than the general rules."17

Jurisdictional rules protect employees by giving them a jurisdictional preference and shielding them from abuse by employers of the latter's typically superior bargaining power. When they act as claimants, employees are given access to more jurisdictional bases than claimant employers; moreover, claimant employees are often given access to one or more jurisdictional bases in addition to those that are available to claimants in general. On the other hand, when employers act as claimants, not only are they given access to fewer jurisdictional bases than claimant employees, claimant employers are often denied the use of some jurisdictional bases that are otherwise available to claimants in general. The jurisdictional preference given to employees, however, must be proportionate to the aim of protection of employees and not too burdensome for employers. The effects of choice-of-court agreements in employment contracts are often restricted in order to protect the operation of nonconsensual jurisdictional bases. The aim is to ensure that employees are able to present their claims in favourable forums and do not have to defend their cases in inaccessible forums.

The rules of jurisdiction in employment matters of the Brussels I Recast offer an example of jurisdictional rules whose aim is to protect employees. ${ }^{18}$ In a nutshell, the Recast allows the employee to sue the employer in several Member States, most importantly in the

\footnotetext{
${ }^{17}$ See also Recitals 14 and 19 of the Brussels I Recast.

18 Whether these rules achieve, in fact, the stated goal of protection of employees is debatable. For a critical analysis see Grušić, supra n 16 in Ch 4.
} 
courts of the employer's domicile, ${ }^{19}$ in the courts for the habitual place of work ${ }^{20}$ or, in the absence of a habitual place of work, in the courts of the engaging place of business. ${ }^{21}$ The last two jurisdictional bases (habitual place of work; engaging place of business) are now open to the claimant employee regardless of whether or not the employer is domiciled in the EU. ${ }^{22}$ The employee, on the other hand, may, in principle, be sued only in the courts of the Member State where he or she is domiciled. ${ }^{23}$ Jurisdiction agreements are effective only if entered into after the dispute has arisen or if they allow the employee to bring proceedings in courts other than those designated by non-consensual jurisdictional bases. ${ }^{24}$

Some systems of private international law support the policy of jurisdictional protection of employees by rules of recognition and enforcement of foreign judgments. Private international laws of some countries provide that a foreign judgment will be refused recognition and enforcement in the situation where the courts of the addressed state have jurisdiction over the employment dispute under the addressed state's protective jurisdictional rules. For example, according to the 2007 study on residual jurisdiction of the courts of EU Member States, the laws of some Member States confer exclusive jurisdiction upon the local courts in matters relating to individual employment contracts that are connected in certain ways with those Member States. In some Member States, such exclusive jurisdiction is a ground for refusal of recognition and enforcement of foreign judgments. ${ }^{25}$ The jurisdictional

\footnotetext{
${ }^{19}$ Art 21(1)(a) of the Brussels I Recast.

${ }^{20}$ Ibid, Art 21(1)(b)(i).

${ }^{21} \mathrm{Ibid}$, Art 21(1)(b)(ii). Also available to employees are the rules of jurisdiction over co-defendants in Art 8(1) and for counter-claims in Art 8(3): ibid, Arts 20(1) and 22(2).

${ }^{22}$ Ibid, Art 21(2).

${ }^{23} \mathrm{Ibid}$, Art 22(1). Also available to employers are the rules of jurisdiction for counter-claims in Art 8(3): ibid, Art 22(2).

${ }^{24}$ Ibid, Art 23. See also ibid, Art 24 (submission).

25 A Nuyts, Study on Residual Jurisdiction: General Report (September 2007) available at http://ec.europa.eu/civiljustice/news/docs/study_residual_jurisdiction_en.pdf, 69, accessed 13 July 2016. See, for example, the French national report on residual jurisdiction, available at http://ec.europa.eu/civiljustice/news/docs/study_resid_jurisd_france_en.pdf, 22, accessed 13 July 2016 (referring to Paris Tribunal de grande instance, 7 February 1986, Rev crit DIP, 1986, p 547, note H GaudemetTallon, JDI 1986, note P Mayer).
} 
defence for employment disputes of the Brussels I Recast serves to ensure the correct application of the Recast's rules of jurisdiction in employment matters.

The rationale for the protection of employees by rules of recognition and enforcement of foreign judgments is twofold. One of the goals of the jurisdictional defence for employment disputes is to protect the private interests of individual employees. According to Cuniberti, ${ }^{26}$ there are two kinds of transnational disputes. Some disputes, e.g. commercial disputes, typically have no personal and symbolic dimension. Other disputes, e.g. employment disputes, typically have a strong personal and symbolic dimension. In the latter kind of disputes, the victim of a wrong who brings a claim is often interested not only in obtaining compensation or other remedies, but also in having his or her day in court and obtaining the non-material benefits that this brings. It is because of this personal and symbolic dimension of a typical employment dispute, coupled with the fact that employees are typically weaker parties vis-à-vis their employers, that the jurisdictional preference given to employees is protected at the stage of recognition and enforcement. If it were not, unscrupulous employers might abuse their typically stronger litigational capacity by commencing disputes in forums that are disadvantageous or even inaccessible to their employees. Employees faced with the prospect of such litigation would have to choose either to defend their cases in such forums or to default and face the prospect of having the default judgment recognised and enforced against them abroad. Sometimes, employees will find it practically impossible to defend their cases in such forums and will have no option but to default.

The law of adjudicatory jurisdiction purports to achieve the objectives of this area of law not only by satisfying and balancing the private interests of litigants, but also often by

\footnotetext{
${ }^{26}$ G Cuniberti, "Some Remarks on the Efficiency of Exequatur" in H Kronke, K Thorn and others (eds), Grenzen überwinden - Prinzipien bewahren: Festschrift für Bernd von Hoffmann zum 70. Geburtstag (Bielefeld: Gieseking, 2011) 568, 572.
} 
vindicating legitimate state interests. ${ }^{27}$ Rules of jurisdiction may be created with the aim of ensuring that the local courts will adjudicate the disputes that touch significantly upon local policies. This connection between adjudicatory jurisdiction and local policies often exists with regard to rules of jurisdiction in employment matters. Choice-of-law rules for employment contracts are typically designed in a way that ensures, among other things, the application of the law of the country that is sufficiently closely connected with the employment contract in question and legitimately interested in regulating it. ${ }^{28}$ Rules of jurisdiction in employment matters often complement choice-of-law rules for employment contracts by conferring jurisdiction on the courts of the country whose law governs the employment contract. In the words of Advocate General Trstenjak in Koelzsch v Luxemburg, a case that concerned the interpretation of choice-of-law rules for employment contracts contained in Article 6 of the Rome Convention, ${ }^{29}$ the

"consistency between forum and ius is desirable, which means that the court with jurisdiction to determine a case should apply the law of its own State. Ideally, the jurisdiction rule would confer jurisdiction on the court of the State the law of which will apply on the basis of the rules of private international law." 30

The fact that there is often this complementarity between rules of jurisdiction in employment matters and choice-of-law rules for employment contracts and the fact that choice-of-law rules for employment contracts are designed, among other things, to lead to the application of the law of the country that is legitimately interested in regulating the employment contract in

\footnotetext{
27 See A T von Mehren, "Theory and Practice of Adjudicatory Authority in Private International Law: A Comparative Study of the Doctrine, Policies and Practices of Common- and Civil-law Systems" (2002) 295 Recueil des Cours 9, 68. See also R Michaels, "Two Paradigms of Jurisdiction" (2006) 27 Michigan Journal of International Law 1003, 1017.

${ }^{28}$ See Grušić, supra n 16 at 38-49 and in general Ch 2.

${ }^{29} 1980$ Rome Convention on the law applicable to contractual obligations [1980] OJ L266/1, now superseded by Regulation (EC) No 593/2008 of the European Parliament and of the Council of 17 June 2008 on the law applicable to contractual obligations [2008] OJ L177/6.

30 Opinion of AG Trstenjak, Case C-29/10 Heiko Kolezsch v État du Grand Duchy of Luxemburg [2011] ECR I1595 [80] (footnote omitted).
} 
question means that there is often a close connection between adjudicatory jurisdiction and state policies. By safeguarding the application of protective rules of jurisdiction, the jurisdictional defence for employment disputes often pursues a second goal of protection of legitimate interests of states to adjudicate the disputes that touch significantly upon their policies.

One might remark that the connection between adjudicatory jurisdiction and state policies is not particularly strong under the Brussels I Recast because the jurisdictional defence for employment disputes safeguards only the application of the rule that the employee may, in principle, be sued only in the courts of the Member State where he or she is domiciled. Nevertheless, given that the vast majority of employees are domiciled and work in the same country and that, therefore, the law of that country applies to their employment contracts, the connection between adjudicatory jurisdiction and state policies is, generally speaking, neither absent nor weak under the Recast. But in cases where the employee is domiciled in one country from which he or she travels to work in another country, it is clear that the goal of vindicating legitimate state interests is subordinated to the goal of protecting the private interests of individual employees.

Every system of private international law that has a jurisdictional defence for employment disputes has to address three questions. The first question is whether this jurisdictional defence can be raised only by employees as typically weaker parties or whether it is open to employers as well. Article 45(1)(e)(i) of the Brussels I Recast clearly provides that this jurisdictional defence is available only when the employee was the defendant in the original proceedings. The second question is whether the courts of the addressed state can review the findings of fact and/or the findings of law of the court of origin on which that court based its jurisdiction in an employment dispute. The Recast is clear in this respect as well. Article 45(2) provides that the court of the Member State addressed is bound by the 
findings of fact (but not by the findings of law) of the court of origin. This reflects a great amount of confidence that the Member States place in each other's administration of justice. ${ }^{31}$ The third question is whether the judge is allowed to raise this jurisdictional defence of its own motion. The Recast unequivocally provides that it is for the judgment debtor to commence special proceedings for refusal of recognition and enforcement and plead and prove in those proceedings all jurisdictional defences.

The next two sections will examine in more detail the recognition and enforcement of judgments in employment matters under the Brussels I Recast, the European Enforcement Order Regulation and the European Order for Payment Procedure Regulation. The aim is to determine whether or not the objective of protection of employees by rules of recognition and enforcement of judgments is undermined at the overlap of the fields of application of these instruments.

\section{Brussels I Recast and recognition and enforcement of judgments in employment matters}

The Brussels I Recast is a double instrument, based on the principle of mutual trust among the Member States. It contains rules of both jurisdiction and recognition and enforcement of judgments. No court within the EU can assume jurisdiction over an EU domiciliary on traditional, often exorbitant, bases, but only pursuant to the Recast's uniform jurisdictional rules that are considered reasonable by all the Member States. The correct application of the Recast's jurisdictional rules is ensured by two mechanisms. First, there are special provisions

\footnotetext{
${ }^{31}$ See A T von Mehren, "Recognition and Enforcement of Foreign Judgments: General Theory and the Role of Jurisdictional Requirements" (1989) 167 Recueil des Cours 9, 83 and 97-98.
} 
on natural justice and on examination as to jurisdiction and admissibility, ${ }^{32}$ which are designed to protect the defendant where he or she has not entered an appearance. Second, the court of origin is under an obligation to submit, in certain circumstances, to the Court of Justice of the European Union a reference for a preliminary ruling on the interpretation of the Recast's jurisdictional rules. ${ }^{33}$ Consequently, the Member States are willing, as a matter of principle, to recognise and enforce judgments given in other Member States without reviewing the jurisdiction of the court of origin. ${ }^{34}$ Furthermore, the comparability of the quality of justice and a degree of similarity in the institutional characteristics of the administration of justice within the EU, which is the foundation for the principle of mutual trust among the Member States, enables keeping other defences to recognition and enforcement to a minimum. ${ }^{35}$

But there are a few exceptions to the rule that the court addressed cannot review the jurisdiction of the court of origin. Most importantly, if the court of origin assumed jurisdiction contrary to the rules of jurisdiction in insurance, consumer and employment matters or the rules of exclusive jurisdiction, the court addressed shall not recognise and enforce the judgment. ${ }^{36}$ The jurisdictional defence for disputes concerning typically weaker parties can only be invoked by the weaker party, i.e. the policyholder, the insured, a beneficiary of the insurance contract, the injured party, the consumer and the employee. ${ }^{37}$ In examining these issues the court addressed is bound by the findings of fact on which the court

\footnotetext{
${ }^{32}$ Arts 27 and 28 of the Brussels I Recast.

${ }^{33}$ Art 267 of the Treaty on the Functioning of the European Union [2010] OJ C83/1.

${ }^{34}$ Art 45(3) of the Brussels I Recast; Case C-7/98 Dieter Krombach v Andre Bamberski [2000] ECR I-1935. It should be noted that the Recast applies to the recognition and enforcement of all judgments given by the courts of the Member States in respect of matters coming within its scope, regardless of whether the court of origin applied the traditional or the Recast's rules of jurisdiction.

35 See A T von Mehren, "Recognition and Enforcement of Sister State Judgments: Reflections on General Theory and Current Practice in the EEC and the US" (1981) 81 Columbia Law Review 1044.

${ }^{36}$ Art 45(1)(e) of the Brussels I Recast.

${ }^{37}$ Ibid, Art 45(1)(e)(i).
} 
of origin based its jurisdiction. ${ }^{38}$ The test of public policy may not be applied to the rules relating to jurisdiction. ${ }^{39}$ The rest of this section will examine, firstly, the importance of the jurisdictional defence for employment disputes under the Brussels I Recast and, secondly, the application of this defence.

\section{Importance of the jurisdictional defence for employment disputes}

In order to demonstrate the importance of the jurisdictional defence for employment disputes under the Brussels I Recast, this sub-section will examine why this jurisdictional defence did not exist under the 2001 Brussels I Regulation and the 1968 Brussels Convention and the reasons for its introduction into the Recast.

The fact that the 2001 Brussels I Regulation accorded different weight to the rules of jurisdiction in employment matters and to the rules of jurisdiction in insurance and consumer matters may seem "inexplicable". ${ }^{40}$ The divergent treatment is indeed difficult to explain on a point of principle given that the three types of jurisdictional rules serve the same purpose the protection of typically weaker parties. The explanation provided by the European Commission in the Explanatory Memorandum accompanying the proposal of the 2001 Brussels I Regulation was that any review of jurisdiction would only affect employees, since

\footnotetext{
${ }^{38}$ Ibid, Art 45(2).

${ }^{39}$ Ibid, Art 45(3).

${ }^{40}$ E B Crawford and J M Carruthers, International Private Law in Scotland (Edinburgh: Thomson/W Green, $2^{\text {nd }}$ ed, 2006) 231, fn 48.
} 
it is them who generally seek recognition and enforcement of judgments. ${ }^{41}$ It seems that some authors accepted this argument. ${ }^{42}$ The majority of authors, however, rejected it. ${ }^{43}$

The Commission's explanation was based on two premises. First, that the disputes in which employees act as defendants are so rare that the protection from wrongful assumption of jurisdiction over them is not necessary. It further assumed that the cases in which employers seek recognition and enforcement of judgments are virtually non-existent. Admittedly, these two situations seldom occur. The analysis of the case-law of the Court of Justice of the European Union on the 2001 Brussels I Regulation and the 1968 Brussels Convention shows that in only two (or potentially three) out of the eighteen cases $^{44}$ raising issues of private international law of employment did employees act as defendants. ${ }^{45}$ No case involving recognition and enforcement of a judgment in employment matters has reached this Court, although this is to be expected given the recent creation of the jurisdictional defence for employment disputes. This suggests that situations in which employees act as claimants are much more frequent than those where they act as defendants. This is hardly surprising. As eloquently stated by Smith and Cromack,

\footnotetext{
${ }^{41}$ European Commission, Explanatory Memorandum accompanying the proposal for a Council Regulation (EC) on jurisdiction and the recognition and enforcement of judgments in civil and commercial matters COM(1999) 348 final, 23.

${ }^{42}$ See M Bogdan, Concise Introduction to EU Private International Law (Groningen: Europa Law, 2006) 78; J J Fawcett and J M Carruthers, Cheshire, North \& Fawcett: Private International Law (Oxford University Press, $14^{\text {th }}$ ed, 2008) 626.

${ }^{43}$ See B Ancel, "The Brussels I Regulation: Comment" (2001) 3 Yearbook of Private International Law 101, 106-107; G A L Droz and H Gaudemet-Tallon, "La transformation de la Convention de Bruxelles du 27 septembre 1968 en Règlement du Conceil concernant la competence judiciaire, la reconnaissance et l'exécution des decision en matière civile et commerciale" (2001) 90 Revue critique de droit international privé 601, 648; J Hill and A Chong, International Commercial Disputes: Commercial Conflict of Laws in English Courts (Hart Publishing, $4^{\text {th }}$ ed, 2010) 455; A A H van Hoek (2001) 38 Common Market Law Review 1011, 1025; A Junker, "Vom Brüsseler Übereinkommen zur Brüsseler Verordnung - Wandlungen des Internationalen Zivilprozessrechts" (2002) 48 Recht der internationalen Wirtschaft 569, 577; P Mankowski in U Magnus and P Mankowski (eds), Brussels I Regulation (Munich: Sellier European Law Publishers, $\left.2^{\text {nd }} e d, 2012\right) 711-712$.

${ }^{44}$ This figure includes three recent references for a preliminary ruling to the Court of Justice of the European Union in Case C-242/16 José Rui Garrett Pontes Pedroso v Netjets Management Limited [2016] OJ C251/16; C-168/16 Sandra Nogueira, Victor Perez-Ortega, Virginie Mauguit, Maria Sanchez-Odogherty, José SanchezNavarro v Crewlink Ltd [2016] OJ C191/18.

${ }^{45}$ Case 288/82 Ferdinand M J J Duijnstee v Lodewijk Goderbauer [1983] ECR 3663; Case C-159/02 Gregory Paul Turner v Felix Fareed Ismail Grovit [2004] ECR I-3565; see also Case C-47/14 Holterman Ferho Exploitatie BV v Spies von Büllesheim EU:C:2015:574, [2015] IL Pr 44, where the defendant was director and manager of a company and it was for the referring court to determine whether he was an employee.
} 
"Employers rarely sue their employees, not because they cannot do so... but because they have a whole armoury of weapons from gradings, salaries, promotions, through disciplinary procedures ultimately to dismissal, to enforce the contract upon the employee."46

However, these were not valid reasons for treating employees differently than the other two categories of weaker parties.

Albeit rarely, situations in which employees act as defendants do occur. Employers regularly bring claims for breach of restrictive covenants and claims for breach of the employee's duty of fidelity and confidentiality. ${ }^{47}$ In certain Member States, such as the Netherlands, employers often petition for judicial rescission of the employment contract instead of dismissal. ${ }^{48}$ Furthermore, employers sometimes initiate vexatious or oppressive proceedings in forums that are foreign to their employees. Indeed, this was the crux of one of the most famous CJEU cases in the field of European private international law, Turner $v$ Grovit. $^{49}$

Mr Turner worked as a solicitor for a group of companies owned by Mr Grovit. He was recruited by, and worked in London for, a UK member of the group. He was transferred to a Madrid office of a Spanish affiliate. The transfer was intended to be temporary. $\mathrm{Mr}$ Turner was still employed and received salary from the UK company. A few months after arriving in Madrid, he found that the whole group was involved in an alleged tax fraud. $\mathrm{He}$

\footnotetext{
${ }^{46}$ R Smith and V Cromack, "International Employment Contracts - the Applicable Law" (1993) 22 Industrial Law Journal 1, 6.

${ }^{47}$ See Swithenbank Foods Ltd v Bowers [2002] EWHC 2257 (QB), [2002] 2 All ER (Comm) 974; WPP Holdings Italy Srl v Benatti [2006] EWHC 1641 (Comm); [2007] 1 All ER (Comm) 208 and [2007] EWCA Civ 263; [2007] 1 WLR 2316; Samengo-Turner v J\&H Marsh \& McLennan (Services) Ltd [2007] EWCA Civ 723; [2007] 2 All ER (Comm) 813; CEF Holdings Ltd v Mundey [2012] EWHC 1524 (QB); [2012] IRLR 912; OJSC TNK-BP Holding v Lazurenko [2012] EWHC $2781(\mathrm{Ch}) ;$ Petter v EMC Europe Ltd [2015] EWCA Civ 828; [2015] IRLR 847.

${ }^{48}$ See A T J M Jacobs, Labour Law in the Netherlands (The Hague: Kluwer Law International, 2004) 138-140.

${ }^{49}$ Case C-159/02 [2004] ECR I-3565; see also Samengo-Turner v J\&H Marsh \& McLennan (Services) Ltd [2007] EWCA Civ 723; [2007] 2 All ER (Comm) 813; Petter v EMC Europe Ltd [2015] EWCA Civ 828; [2015] IRLR 847.
} 
was expected to justify and defend this. Since he could not do so, Mr Turner resigned and returned to England where he commenced proceedings against the UK employer for unfair and wrongful dismissal. The Employment Tribunal assumed jurisdiction and decided in his favour. Mr Grovit responded by initiating proceedings against Mr Turner in Spain in the name of the Spanish company where Mr Turner had worked. The Spanish company alleged that it had entered an employment contract with Mr Turner, failed to inform the Spanish court of the English Employment Tribunal's decision on jurisdiction, and claimed almost $£ 500,000$ in damages for breach of contract. This claim was vexatious and oppressive. It aimed at putting Mr Turner under financial pressure and forcing him to settle on Mr Grovit's terms. This was recognised by the English Court of Appeal which granted an anti-suit injunction against the UK and Spanish companies and Mr Grovit. ${ }^{50}$ This case eventually went to the CJEU, which held that the courts of the Member States are prohibited from granting injunctions restraining a party from commencing or continuing proceedings before a court of another Member State. ${ }^{51}$

If the employer initiates proceedings outside the country of the employee's domicile, there is always a risk that the foreign court might wrongly assume its jurisdiction. Under the 2001 Brussels I Regulation, the possibility of wrongful assumption of jurisdiction, combined with the effects of lis pendens ${ }^{52}$ and the lack of jurisdictional defence at the recognition and enforcement stage, forced the employee to participate in foreign proceedings, hire a foreign lawyer and challenge the foreign court's jurisdiction. If he or she failed to do so, the employee risked having a default judgment rendered against him or her on the basis of the facts and law presented by the employer, which judgment enjoyed free movement throughout

\footnotetext{
${ }^{50}$ [1999] 3 WLR 794 (CA).

${ }^{51}$ Case C-159/02 Gregory Paul Turner v Felix Fareed Ismail Grovit [2004] ECR I-3565.

${ }^{52}$ Arts 27-30 of the 2001 of the Brussels I Regulation; Arts 29-34 of the Brussels I Recast.
} 
the EU. This was contrary to the aim of the protective jurisdictional rules in employment matters, which seek to afford employees the privilege of defending in their home country.

A pressure of this kind was absent on the part of the other two categories of typically weaker parties. Judgments of foreign courts that wrongly assumed jurisdiction over insured persons or consumers could not be recognised and enforced within the EU. The Commission's explanation that employees do not need an analogous protection because "it is them who generally seek recognition and enforcement of foreign judgments" 53 was not persuasive. As Ancel aptly remarked: "This logic [was] astonishing ... in so far as it devalue[d] a jurisdictional competence that it propose[d] to reinforce." ${ }^{, 54}$

Despite the Commission's explanation, it seems that the main reason why the 2001 Brussels I Regulation treated employees differently from insured persons and consumers was the haphazard evolution of its rules of jurisdiction in employment matters. ${ }^{55}$ The original 1968 version of the Brussels Convention did not contain any special jurisdictional rules for employment disputes. It did, however, contain protective jurisdictional rules for matters relating to insurance (Section 3 of Title II) and instalment sales and loans (Section 4 of Title II). Article 28 reinforced this protection by providing that a judgment conflicting with these protective rules should be refused recognition and enforcement. The special rules of jurisdiction in employment matters were firstly introduced in Articles 5(1) and 17(5) of the 1988 Lugano Convention and then in 1989 in the Brussels Convention. ${ }^{56}$ These two Articles, however, also dealt with the assumption of jurisdiction in general contractual matters and the validity of choice-of-court agreements in general, respectively. Since the special rules for employment disputes were embedded in the general rules, the two Conventions did not allow

\footnotetext{
${ }^{53}$ Supra $\mathrm{n} 41$.

${ }^{54}$ Ancel, supra $\mathrm{n} 43$ at 107.

${ }_{55}^{5}$ For a detailed account of this evolution see Grušić, supra n 16 at 95-100.

${ }^{56}$ Convention on the accession of the Kingdom of Spain and the Portuguese Republic to the Convention on jurisdiction and the enforcement of judgments in civil and commercial matters [1989] OJ L285/1.
} 
the review of jurisdiction as regards judgments in employment matters. The reason why the 2001 Brussels I Regulation was left unchanged in this respect was either an oversight or a lack of political consensus. ${ }^{57}$

In conclusion, there are good theoretical and practical reasons for allowing the review of the correctness of the application of the rules of jurisdiction in employment matters at the stage of recognition and enforcement. The Commission's remark that "it is [employees] who generally seek recognition and enforcement of foreign judgments" ${ }^{\text {"5 }}$ could easily be accommodated by entitling only employees to invoke the jurisdictional defence. These are precisely the two changes that the Recast of the Brussels I Regulation introduced into the grounds for refusal or recognition.

\section{Application of the jurisdictional defence for employment disputes}

The most important change introduced by the Brussels I Recast is the abolition of exequatur.

This means that it is left to those who want to oppose recognition and enforcement to commence special proceedings for refusal of recognition and enforcement by invoking the grounds for refusal available under the Recast. The conflict of a judgment with the rules of jurisdiction in employment matters is a new ground for refusal of recognition (and, therefore, enforcement), so there is still no case law on its interpretation. One, therefore, has to look into

\footnotetext{
57 According to A Briggs and P Rees, Civil Jurisdiction and Judgments (Informa, 5 $5^{\text {th }}$ ed, 2009) 155, the explanation lies in the fact that the rules of jurisdiction in employment matters "evolved in piecemeal fashion. They were not fashioned as jurisdictional rules which enjoyed [the] privileged status when it came to recognition of judgments." Crawford and Carruthers, supra n 40 at 231, fn 48, state that "this omission ... [has] arisen from mere oversight". According to T Hartley, International Commercial Litigation: Text, Cases and Materials on Private International Law (Cambridge University Press, 2009) 324, the special treatment given to the cases concerning insurance, consumer contracts and exclusive jurisdiction is "[p]resumably ... the result of a political compromise." Mankowski, supra n 43 at 712, is of the opinion that "political agreement could simply not be reached".

${ }^{58}$ Supra $\mathrm{n} 41$.
} 
the case law on the jurisdictional defences for insurance and consumer matters and disputes concerning exclusive jurisdiction of Member State courts to understand the application of the jurisdictional defence for employment disputes.

Article 45(1)(e) applies where the court of origin assumed jurisdiction under the Recast, i.e. either under the Recast's jurisdictional rules or - as provided for in Article 6 under the forum's traditional jurisdictional rules. The defendant in the original proceedings who is invoking the jurisdictional defence for employment disputes in Article 45(1)(e)(i) in the Member State addressed will have to prove the following three points: 1) that he or she and the claimant in the original proceedings were parties to an individual employment contract; ${ }^{59}$ 2) that the dispute concerned a matter relating to the individual employment contract; $^{60}$ 3) that the judgment conflicts with the Recast's rules of jurisdiction in employment matters. ${ }^{61}$

Article 45(1)(e) is an exception to the principle of mutual trust according to which the courts of the Member State addressed should assume that the court of origin correctly applied the Recast's uniform jurisdictional rules. ${ }^{62}$ Because it is an exception to this fundamental principle, the application of Article 45(1)(e) is limited. The jurisdictional defence for employment disputes can only be raised by the employee, not the employer. Article 45(1)(e) allows the courts of the Member State addressed to examine only the international jurisdiction of the court of origin. The correctness of the application of the rules concerning venue or subject-matter jurisdiction of the court of origin cannot be reviewed under Article

\footnotetext{
${ }^{59}$ For the notion of "individual employment contract" for the purposes of European private international law see Grušić, supra n 16 in Ch 3 and Case C-47/14 Holterman Ferho Exploitatie BV v Spies von Büllesheim EU:C:2015:574, [2015] IL Pr 44.

${ }^{60}$ For the interpretation of the wording "matters relating to an individual employment contract" for the purposes of the Brussels I Recast see Grušić, ibid, 92-93 and 235-236.

${ }^{61}$ See Case C-111/09 Česká podnikatelská pojištovna as, Vienna Insurance Group v Michal Bilas [2010] ECR I-4545 [28]-[29].

${ }^{62}$ Case C-456/11 Gothaer Allgemeine Versicherung AG and Others v Samskip GmbH ECLI:EU:C:2012:719, [2013] QB 548 [37].
} 
45(1)(e). ${ }^{63}$ The jurisdictional defence is available only if the court of origin failed to apply the rules of jurisdiction in employment matters which confer jurisdiction on the courts of another Member State, regardless of whether or not that Member State is the Member State addressed. If the domicile of the employee, being the connecting factors on which the rule of jurisdiction that is protected by the jurisdictional defence for employment disputes is based, points to a non-Member State, the jurisdictional defence does not apply. ${ }^{64}$

The application of Article 45(1)(e) is further limited by a provision stating that the court of the Member State addressed is bound by the findings of fact of the court of origin. ${ }^{65}$ This means that the courts of the Member State addressed can review the international jurisdiction of the court of origin only on the basis of the findings of facts of that court. The courts of the Member State addressed cannot re-open or re-examine the facts, admit new evidence, or take into account facts that have arisen after the original proceedings. What the courts of the Member State addressed are allowed to review are findings of law of the court of origin, such as whether the parties in the original proceedings were bound by an individual employment contract, whether the dispute in the original proceedings concerned a matter relating to the individual employment contract, whether the employee was domiciled in the Member State of origin or another Member State or whether the jurisdiction of the court of origin was correctly assumed on another permissible basis. But there has to be one exception to this rule. If the court of origin made no findings of fact or if these findings of fact have not been communicated to the courts of the Member State addressed, as happens for example in the case of judgment lacking reasons, ${ }^{66}$ the courts of the Member State addressed should be

\footnotetext{
${ }^{63}$ Case C-420/07 Meletis Apostolides v David Charles Orams and Linda Elizabeth Orams [2009] ECR I-3571 [47]-[52].

${ }^{64}$ See A Briggs, Civil Jurisdiction and Judgments (Informa, $6^{\text {th }}$ ed, 2015) para 7.10; Mankowski, supra n 43 at 706-707.

${ }^{65}$ Art 45(2) of the Brussels I Recast.

${ }^{66}$ See G Cuniberti, "The Recognition of Foreign Judgments Lacking Reasons in Europe: Access to Justice, Foreign Court Avoidance, and Efficiency” (2008) 57 International and Comparative Law Quarterly 25.
} 
allowed to conduct a necessary examination of the factual basis on which the court of origin assumed jurisdiction. ${ }^{67}$

A question that was left open by the CJEU in Hans-Hermann Mietz $v$ Intership Yachting Sneek $B V^{68}$ is whether the courts of the Member State addressed are allowed to review the jurisdiction of the court of origin in the situation where the defendant in the original proceedings appeared in those proceedings, but failed to contest the jurisdiction of the court of origin by invoking the protective jurisdictional rules. In Mietz, one of the questions before the CJEU was whether the party who opposed the recognition and enforcement of a Dutch judgment in Germany should be allowed to raise a new argument that he was a consumer and that the judgment of the court of origin was contrary to the rules of jurisdiction over consumer contracts. The CJEU did not answer this question, since it decided the case on the basis of interpretation of the conditions under which a provisional measure given in one Member State could be recognised and enforced in another Member State. It seems that the answer to this question must be in the negative. If a party appears in the original proceedings and fails to argue that he or she falls into a category of typically weaker parties who are accorded a jurisdictional preference, that party should be considered to have waived the protection offered by the jurisdictional defence in Article 45(1)(e)(i). ${ }^{69}$ This conclusion finds support in Česká podnikatelská pojištovna as, Vienna Insurance Group v Michal Bilas, ${ }^{70}$ where the CJEU found that the jurisdictional protection offered to a weaker party can be waived by appearance in accordance with what is now Article 26 of the Recast. ${ }^{71}$

\footnotetext{
${ }^{67}$ Also Fitchen, supra n 8 at para 13.394. See also Mankowski, supra n 43 at 717.

${ }^{68}$ Case C-99/96 [1999] ECR I-2277.

${ }^{69}$ Also Fitchen, supra $\mathrm{n} 8$ at para 13.394.

${ }^{70}$ Case C-111/09 [2010] ECR I-4545, noted by U Grušić (2011) 48 Common Market Law Review 947.

${ }^{71}$ Where appearance has been entered to contest the jurisdiction of the court of origin, there is no submission to the jurisdiction of that court: Art 26(1) of the Brussels I Recast. It should also be mentioned that, unlike the equivalent Art 24 of the 2001 Brussels I Regulation, Art 26 of the Brussels I Recast provides the following, in para 2: In matters referred to in Sections 3, 4 or 5 where the policyholder, the insured, a beneficiary of the insurance contract, the injured party, the consumer or the employee is the defendant, the court shall, before
} 
Finally, the application of Article 45(1)(e) is also limited by a provision stating that the test of public policy referred to in Article 45(1)(a) may not be applied to the rules relating to jurisdiction. This means that the judgment debtor cannot circumvent the restrictive nature of the jurisdictional defences by arguing that the assumption of jurisdiction by the court of origin violates the public policy of the Member State addressed. But public policy can arguably be raised to oppose the assumption of jurisdiction by the court of origin if the claimant in the original proceedings obtained the jurisdiction of the court of origin in a fraudulent way. ${ }^{72}$

\section{The European Enforcement Order Regulation and the European Order for Payment Procedure Regulation and recognition and enforcement of judgments in employment matters}

The preceding sections have shown that the jurisdictional defence for employment disputes performs a useful theoretical and practical role under the Brussels I Recast. Recognition and enforcement of judgments in civil and commercial matters are also governed by three other European instruments, the European Enforcement Order Regulation, the European Order for Payment Procedure Regulation and the European Small Claims Procedure Regulation. The last of these instruments expressly excludes employment matters from its scope. ${ }^{73}$ The European Enforcement Order Regulation and the European Order for Payment Procedure Regulation do not state whether or not they apply to employment matters and do not guarantee employees that their jurisdictional privileges will be respected by the court of

\footnotetext{
assuming jurisdiction under paragraph 1 , ensure that the defendant is informed of his right to contest the jurisdiction of the court and of the consequences of entering or not entering an appearance.

${ }_{72}$ Briggs, supra $\mathrm{n} 64$ at para 7.10, fn 105.

${ }^{73}$ Art 2(2)(f) of the Small Claims Procedure Regulation.
} 
origin. This section will examine whether these two instruments apply to employment matters and, if so, whether the application of these instruments, at the overlap of their fields of application with that of the Brussels I Recast, has the potential to undermine the goal of protection of employees, as enshrined in Article 45(1)(e)(i) of the Recast.

\section{The European Enforcement Order Regulation}

The European Enforcement Order Regulation introduces a simplified recognition and enforcement procedure for judgments on uncontested claims. It authorises the court of origin to issue a certificate in a specified standard form showing that the minimum standards set by this Regulation are met. The judgment, thus certified as a European enforcement order, enjoys almost unimpeded free movement throughout the EU. ${ }^{74}$ The procedure established by this Regulation is optional. The judgment creditor may seek recognition and enforcement of a judgment on an uncontested claim under either the European Enforcement Order Regulation or the 2001 Brussels I Regulation/Brussels I Recast. ${ }^{75}$

The subject-matter scope of the European Enforcement Order Regulation is virtually the same as that of the Brussels I Recast. ${ }^{76}$ Judgments in employment matters are not expressly excluded. The concept of "uncontested claims" is said to cover all situations in which a creditor, given the verified absence of any dispute by the debtor as to the nature or extent of a pecuniary claim for a specific amount, has obtained a judgment against the debtor. "77 "Claim" for the purposes of this Regulation means a claim for payment of a specific

\footnotetext{
${ }^{74}$ Arts 1 and 5 of the European Enforcement Order Regulation.

75 Ibid, Art 27 provides that this Regulation will not affect the possibility of seeking recognition and enforcement under the 2001 Brussels I Regulation, which has now been replaced by the Brussels I Recast.

${ }^{76}$ Ibid, Art 2.

${ }^{77}$ Ibid, Recital 5.
} 
sum of money that has fallen due or for which the due date is indicated in the judgment. ${ }^{78} \mathrm{~A}$ claim is regarded as "uncontested" in the following alternative situations: the debtor has expressly agreed to it; ${ }^{79}$ the debtor never objected to the claim in the course of the court proceedings, ${ }^{80}$ the debtor did not appear or was not represented at a court hearing regarding that claim after having initially objected to the claim in the course of the court proceedings, provided that such conduct amounts to a tacit admission of the claim or of the facts alleged by the creditor under the law of the country of origin. ${ }^{81}$

It seems that at least some claims that employers bring against employees are capable of being covered, e.g. where the employment contract specifies the amount of damages for breach of its provisions or another amount to be paid by the employee and the due date (e.g. an obligation on the part of the employee to repay the sum of money received as a bonus or another liquidated sum if he or she engages in activities detrimental to the employer as determined following the employer's disciplinary procedures). ${ }^{82}$ In addition, the employee would have to expressly agree to the claim, refrain from objecting to the claim, or refuse to participate in the original proceedings after having initially objected to the claim in the course of the court proceedings.

Before certifying a judgment as a European enforcement order, the court of origin must verify that a number of requirements are met: the judgment is enforceable in the country of origin $;{ }^{83}$ the judgment does not conflict with the rules of jurisdiction in insurance matters

\footnotetext{
${ }^{78}$ Ibid, Art 4(2).

${ }^{79}$ Ibid, Art 3(1)(a) and 3(1)(d).

${ }^{80} \mathrm{Ibid}$, Art 3(1)(b).

${ }^{81}$ Ibid, Art 3(1)(c).

${ }^{82}$ See Samengo-Turner v J\&H Marsh \& McLennan (Services) Ltd [2007] EWCA Civ 723; [2007] 2 All ER (Comm) 813. It should be noted that there are other interpretations of the meaning of "claim" for the purposes of the European Enforcement Order Regulation that do not seem to cover claims brought by the employer against the employee: see Briggs, supra n 64 at para 7.32. But see the identically worded Art 4 of the European Order for Payment Procedure Regulation which, at least in the view of the European Commission, is capable of covering employment matters: see text accompanying infra $\mathrm{n} 100$.

${ }^{83}$ Art 6(1)(a) of the European Enforcement Order Regulation.
} 
and exclusive jurisdiction of the Brussels I Recast ${ }^{84}$ the original proceedings met certain minimum procedural standards where the debtor has not expressly admitted the claim; ${ }^{85}$ and, if the debtor is a consumer who has not expressly admitted the claim, the judgment was given in the country of the consumer's domicile. ${ }^{86}$ The judgment debtor may request rectification or withdrawal of the European enforcement order certificate in the country of origin if there is an error in the certificate or if it was clearly wrongly granted ${ }^{87}$ In addition, the debtor is entitled to a review of the order in the country of origin if he or she was not duly informed about the proceedings or was justifiably prevented from contesting the claim. ${ }^{88}$ As can be seen from this brief presentation of the requirements set by the European Enforcement Order Regulation, insured persons and consumers are given a guarantee that their jurisdictional privileges will be respected by the court of origin. Moreover, the jurisdictional privilege given to consumers under the European Enforcement Order Regulation is more generous than the jurisdictional privilege given to consumers under the Brussels I Recast. Under the former instrument, the only acceptable basis of jurisdiction is the consumer's domicile; the assumption of jurisdiction on the basis of a jurisdiction agreement or submission is not recognised ${ }^{89}$ But the conflict of the judgment with the rules of jurisdiction in employment matters is not an obstacle to having the judgment certified as a European enforcement order.

A judgment which has been certified as a European enforcement order must be recognised and enforced throughout the EU without the need for a declaration of enforceability and without any possibility of opposing its recognition. ${ }^{90}$ Enforcement, however, will be refused, upon application by the debtor, if the judgment certified as a

\footnotetext{
${ }^{84}$ See ibid, Art 6(1)(b).

${ }^{85} \mathrm{Ibid}$, Art 6(1)(c). The minimum standards are laid down in Chapter III of this Regulation and relate to the service of documents instituting the proceedings and to the provision of information.

${ }^{86}$ Ibid, Art 6(1)(d). See Case C-508/12 Walter Vapenik v Josef Thurner EU:C:2013:790, [2014] 1 WLR 2486.

${ }^{87}$ Ibid, Art 10.

${ }^{88}$ Ibid, Art 19(1).

${ }^{89}$ Also Fawcett and Carruthers, supra n 42 at 645, fn 445.

${ }^{90}$ Art 5 of the European Enforcement Order Regulation.
} 
European enforcement order is irreconcilable with an earlier judgment given in a Member State or in a third country. ${ }^{91}$ There are also powers to stay or limit the enforcement proceedings where the judgment debtor has challenged the judgment, applied for its review or applied for the rectification or withdrawal of the European enforcement order certificate in the country of origin..$^{92}$

\section{European Order for Payment Procedure Regulation}

The European Order for Payment Procedure Regulation lays down a summary procedure for cross-border cases concerning uncontested pecuniary claims. Judgments rendered pursuant to this procedure qualify for certification as European orders for payment which enjoy free circulation throughout the EU. ${ }^{93}$ This procedure is optional and the claimant may resort to other procedures available under national or EU law. ${ }^{94}$

The European order for payment procedure is established for the collection of pecuniary claims for a specific amount that has fallen due at the time when the application for a European order for payment is submitted. ${ }^{95}$ According to the European Commission's proposal of the European Order for Payment Procedure Regulation, “pecuniary claims for a specific amount that has fallen due" refers to liquidated and payable pecuniary claims and not to "money claims that cannot be specified in terms of a concrete amount (as in the case of immaterial damages, for example) and [to] demands that concern obligations to act or to

\footnotetext{
${ }^{91}$ Ibid, Art 21(1). Irreconcilability can only be invoked if it was not and could not have been raised before the court of origin: Art 21(1)(c). See also Art 22 which safeguards the treaties on jurisdiction and recognition and enforcement of judgments entered into with third countries pursuant to Art 59 of the 1968 Brussels Convention.

92 Ibid, Art 23.

${ }^{93}$ Art 1(1) of the European Order for Payment Procedure Regulation.

${ }^{94}$ Ibid, Art 1(2).

${ }^{95} \mathrm{Ibid}$, Art 4.
} 
refrain from a certain action, such as the delivery or restitution of property or eviction". ${ }^{96}$ This regulation applies to civil and commercial matters ${ }^{97}$ in cross-border cases. ${ }^{98}$ But claims arising from non-contractual obligations are in principle excluded. ${ }^{99}$

As mentioned above in the context of discussion of the European Enforcement Order Regulation, it seems that at least some claims that employers bring against employees are capable of being covered by the term "pecuniary claims for a specific amount that has fallen due" as long as they refer to liquidated and payable pecuniary claims and not to money claims that cannot be specified in terms of a concrete amount. It is also worth mentioning in this respect that the European Commission stated in the proposal for the European Order for Payment Procedure Regulation that:

"The mere jurisdiction of specialised courts or tribunals (e.g. labour tribunals for claims arising out of employment) instead of ordinary civil courts does not constitute a persuasive ground for not admitting an order for payment procedure."100

For the purposes of applying this Regulation, jurisdiction is to be determined in accordance with the Brussels I Recast. ${ }^{101}$ It is specifically provided that where the claim is

\footnotetext{
${ }^{96}$ European Commission, Proposal for a Regulation of the European Parliament and of the Council creating a European order for payment procedure COM(2004) 173 final, 10.

${ }^{97}$ Art 2 of the European Order for Payment Procedure Regulation.

98 Ibid, Art 3(1) defines "cross-border cases" as cases in which at least one of the parties is domiciled or habitually resident in a Member State other than the Member State of the court seized.

${ }^{99}$ Ibid, Art 2(2)(d).

${ }^{100}$ European Commission supra n 96, 9; see also ibid, 16. As can be seen in European Commission, Green Paper on a European order for payment procedure and on measures to simplify and speed up small claims litigation COM (2002) 746 final, the order for payment procedure is available in employment disputes in some Member States such as Sweden (para 3.2.1, fn 37), Germany (para 3.3.2, fn 51; para 3.3.9.1, fn 86; para 3.3.11.2, fn 105) and Austria (para 3.3.12, fn 113), while it is expressly excluded in Luxemburg (para 3.2.2, fn 41). In the Green Paper, the Commission, in para in 3.2.2, dealt with the question of whether certain types of claims should be excluded from the European order of payment procedure. In the opinion of the Commission, "Any such limitation would appear to be justified only in case of a compelling need to exclude certain subject matters from the scope of application of the procedure. For example, a typical structural weakness of defendants in specific areas may be assessed as jeopardizing the adequate protection of the rights of the defence in spite of the possibility to contest the claim and thus prevent an enforceable decision from coming into being." The only "structural weakness" that the European Order for Payment Procedure Regulation recognises concerns consumer contracts. Employment contracts are not expressly excluded or specifically dealt with in any way.

${ }^{101}$ See Art 6(1) of the European Order for Payment Procedure Regulation.
} 
brought against a consumer, only the courts of the consumer's domicile have jurisdiction. ${ }^{102}$ An equivalent provision that would reiterate the importance of jurisdictional rules in employment matters or grant a further more generous jurisdictional privilege to employees than the rules of the Recast does not exist.

The court seized of an application for a European order for payment will issue the order after a summary verification, on the basis of the application form, that the mentioned requirements are met and that the claim appears to be founded. ${ }^{103}$ The order invites the defendant to pay or to oppose the order. ${ }^{104}$ The order must be served on the defendant in compliance with certain minimum procedural safeguards. ${ }^{105}$ If the defendant lodges a statement of opposition, within thirty days of service of the order, the European order for payment procedure is terminated and the proceedings continue without prejudice before the competent court in accordance with the rules of ordinary civil procedure unless the claimant has explicitly requested the termination of the proceedings. ${ }^{106}$ If the defendant fails to lodge a timely statement of opposition, the order becomes enforceable. ${ }^{107}$ After the expiry of the thirty-day time limit, the defendant is entitled to have the order reviewed in the country of origin if he or she was not duly informed about the order or was justifiably prevented from opposing it, ${ }^{108}$ or if the order was clearly wrongly issued. ${ }^{109}$

European payment orders enjoys freedom of movement throughout the EU. ${ }^{110}$ Enforcement will be refused only in the case of irreconcilability ${ }^{111}$ or if, and to the extent

\footnotetext{
102 Ibid, Art 6(2).

${ }^{103} \mathrm{Ibid}$, Arts 8 and 12(1).

${ }^{104}$ Ibid, Art 12(3).

${ }^{105}$ Ibid, Arts 12(5) and 13-15.

106 Ibid, Art 17(1).

${ }^{107}$ Ibid, Art 18(1).

${ }^{108}$ Ibid, Art 20(1).

${ }^{109}$ Ibid, Art 20(2).

${ }^{110}$ Ibid, Art 19.

${ }^{111}$ Ibid, Art 22(1).
} 
that, the defendant has paid the claimant the amount awarded in the order. ${ }^{12}$ Furthermore, there are powers to stay or limit the enforcement proceedings where the judgment debtor has applied for a review of the order in the country of origin. ${ }^{113}$

\section{Do the European Enforcement Order Regulation and the European Order for Payment} Procedure Regulation have the potential to undermine the goal of protection of employees?

The preceding discussion discloses two important things. First, the European Enforcement Order Regulation and the European Order for Payment Procedure Regulation apply to employment matters. The former instrument covers claims for payment of a specific sum of money that has fallen due or for which the due date is indicated in the judgment. Claims of this type that employers bring against employees are covered provided the employee has either expressly agreed to the claim, refrained from objecting to the claim, or refused to participate in the original proceedings after having initially objected to the claim in the course of the court proceedings. The latter instrument also covers uncontested claims for payment of a specific sum that has fallen due. Second, the two instruments guarantee other categories of typically weaker parties, namely insured persons and consumers, that their jurisdictional privileges will be respected by the court of origin. Moreover, the jurisdictional privilege given to consumers under the two instruments is more generous than the jurisdictional privilege given to consumers under the Brussels I Recast. The Brussels I Recast's solution which accords equal weight to the rules of jurisdiction in employment matter and the rules of jurisdiction in consumer and insurance matters was not adopted in the European Enforcement Order Regulation and the European Order for Payment Procedure Regulation. This is not

\footnotetext{
${ }^{112}$ Ibid, Art 22(2).

${ }^{113}$ Ibid, Art 23
} 
surprising, since the 2001 Brussels I Regulation, which also did not contain a jurisdictional defence for employment disputes, was in force when these two instruments were adopted.

The procedures established by the European Enforcement Order Regulation and the European Order for Payment Procedure Regulation are optional. In other words, the judgment creditor may seek recognition and enforcement of a judgment on an uncontested claim under either the European Enforcement Order Regulation or the 2001 Brussels I Regulation/Brussels I Recast. The claimant who has a pecuniary claim for a specific amount that has fallen due can either seek a European order for payment, which can be recognised and enforced throughout the EU under the European Order for Payment Procedure Regulation or commence proceedings in accordance with the rules of ordinary civil procedure and have the resulting judgment recognised and enforced under the Brussels I Recast. In situations where the European Enforcement Order Regulation and the European Order for Payment Procedure Regulation are (potentially) engaged, defendant employees are under pressure to participate in the original proceedings. Moreover, the European Order for Payment Procedure Regulation forces the employee to lodge a statement of opposition to a European enforcement order within thirty days of service of the order without giving the employee the possibility of having the order reviewed after the expiry of this time period in cases of clear misapplication of the jurisdictional rules in employment matters. If the original proceedings are commenced outside of the country of the employee's domicile, the inconvenience of participating in foreign proceedings might be such that the employee is practically barred from participating in those proceedings. The employee who fails to participate in the original proceedings risks having a default judgment or a European order for payment rendered against him or her on the basis of the facts and law presented by the employer, which judgment or order enjoys free movement throughout the EU under the European Enforcement Order Regulation or the European Order for Payment Procedure 
Regulation. The fact that these two instruments do not guarantee employees that their jurisdictional privileges will be respected by the court of origin has the potential to undermine the protection offered by the jurisdictional rules in employment matters and the jurisdictional defence for employment disputes of the Brussels I Recast.

\section{E. Conclusion}

This article deals with the recognition and enforcement of judgments in employment matters in European private international law. It shows that there are good theoretical and practical reasons for allowing the review, at the stage of recognition and enforcement, of the correctness of the application of the rules of jurisdiction in employment matters and that the new jurisdictional defence for employment disputes in Article 45(1)(e)(i) of the Brussels I Recast plays a useful role. The introduction of this jurisdictional defence in the Recast is a

welcome development that has eliminated the inconsistency with regard to jurisdictional defences that existed under the 2001 Brussels I Regulation and the 1968 Brussels Convention, under which only the conflict with the rules of jurisdiction in insurance and consumer matters and exclusive jurisdiction was a ground for the refusal of recognition (and, therefore, enforcement) of a judgment from another Member State.

But the Brussels I Recast is not the only instrument of European private international law that applies to the recognition and enforcement of judgments in employment matters. The European Enforcement Order Regulation and the European Order for Payment Procedure Regulation also apply to employment matters and cover uncontested claims for payment of a specific sum of money that has fallen due. These two instruments do not contain a jurisdictional defence, although they do contain certain guarantees that the jurisdictional 
privileges given to the other categories of typically weaker parties, namely insured persons and consumers, will be respected by the court of origin. This means that these two instruments, at the overlap of their fields of application with that of the Brussels I Recast, have the potential to undermine the protection offered by the Recast's jurisdictional defence for employment disputes.

The relationship between and among the European private international law instruments that apply to the recognition and enforcement of judgments in civil and commercial matters should be reconsidered in any future review or recast process of the European Enforcement Order Regulation and the European Order for Payment Procedure Regulation. ${ }^{114}$ The lack of guarantees for the correct application of the rules of jurisdiction in employment matters is not as important as some of the other deficiencies exhibited by these instruments, e.g. the impossibility to raise a violation of the human rights of the parties, in particular their right to a fair trial, by the court of origin or a violation of the public policy of the Member State addressed following the issuance of the European enforcement order certificate or the European order for payment. Nevertheless, the lack of guarantees for the correct application of the rules of jurisdiction in employment matters should be corrected when the opportunity arises in order to establish coherence between and among the instruments of European private international law.

${ }^{114}$ See supra $\mathrm{n} 15$. 